\title{
Modeling the Effects of Intellectual Capital on Decision Making - A Study of Interaction Moderation with Knowledge Management Process
}

\author{
Rama Bhardwaj \\ PG Department of Computer Science \& IT \\ DAV, College, Amritsar
}

\author{
Hardeep Singh, PhD \\ Department of Computer Science \\ Guru Nanak Dev University, Amritsar
}

\begin{abstract}
Knowledge management provides a budding class to decision making that itself rest on the bench of intellectual capital. However, the present study attempts to extract the relationship between intellectual capital and decision making in egovernance systems in Indian public sector. The study identified the moderating effect of knowledge management process on the relationship between intellectual capital and decision making. However, it showed that all what is required is an ideal combination of human, structural or relational capital with that of the various stages of knowledge management process for an effective decision-making. Consequently, the findings of the present study have practical contributions to the government organizations that may serve as a reference for government organization in the implementation of effective KM system for the decisionmaking in their work culture.
\end{abstract}

\section{Keywords}

Knowledge Management, Decision Making, Intellectual Capita, Moderation Effect, Human Capital, Structural Capital

\section{INTRODUCTION}

\subsection{Relevance of Knowledge Management in Decision Making}

E-governance presents a vital tool to cope with the information explosion in the recent years [38]. Each innovative progress in terms of technology makes $\mathrm{KM}$ inexorably manageable and essential resource in decisionmaking for the future. Since it utilizes various ways for information verification and its application to day by day issues and circumstances, it reduces expensive time for decision making. It also purge the ambiguities by creating a $\log$ of authorization of who has approved certain decisions [42].

At national levels, KM incorporate the improvement of systems that catalyzes the appropriation of KM in government and business divisions thus catering to the needs of development of innovation in various sector - social, economic, science and technology. It further saddles the knowledge base for spurring the innovative and imaginative soul of citizens [52]. In an era of globalization, privatization and liberalization, the knowledge management has become an inevitable choice for e-governance for the survival of economies [42].

Information is a vital asset that can crucially affect decisionmaking in organizations [53]. Moreover, the creation of valuable decision in the light of generation of knowledge is a key factor because of the need of confronting changes in the technological environment [12]. The decision making and knowledge management are co-dependent. The basic decision-making process itself brings about enhanced understanding of the problem and the procedure, and creates new knowledge [9].

\subsection{Intellectual Capital, Knowledge Management and Decision Making}

The organizational knowledge is the intellectual capital and the knowledge management is the process that comprehends such knowledge [24]. Though the basic essence of intellectual capital remains the same, the researchers have categorized it into various forms i.e. human capital, structural capital and relational capital [47, 32]; human capital, organizational capital, and social capital $[24,33,34]$ and even into human capital, organizational capital and relational capital

According to Wiig [54] intellectual capital and knowledge management form the basis of any organization and cannot be pursued independent of each other. A conceptual relationship between intellectual capital and knowledge management has been advocated in the prior studies. A few studies deals with the empirical investigation of the relationship between intellectual capital and organizational performance [29]. In addition to this, the empirical evaluation of $\mathrm{KM}$ and intellectual capital has also been made. The researchers have also investigated how the knowledge management moderates the relationship between intellectual capital and organizational performance [32,55].

\section{RESEARCH BACKGROUND}

Paprika [45] proposed a decision path framework so as to analyze the link between decision making and knowledge management. The framework here depicted that knowledge management has a valuable contribution in the phases of decision making process. He further emphasized that the knowledge that is required varies in accordance with nature as well as the context of the problem. Rolland [46] demonstrated that $\mathrm{KM}$ has a genuine participation in the decision making process. However, the researcher also explored that knowledge transformations and fluctuations may occur over the various phases of decision making process. Furthermore, Olzen et al. [56] stressed upon the complexity of context in case of decision making. The study made a significant contribution to DSS and KM research by showing the nature of the impact that KMS sophistication has upon decision support. More specifically, the study establishes that the value of sophisticated KMS for decision support depends upon context complexity.

Bolloju, Khalifa and Turban [9] proposed the usage of knowledge discovery techniques for integrating decision support and knowledge management processes. Also an integrated framework for building up an Enterprise Decision Support environment has been framed that is centered on the 
formulated approach. In this framework, repositories are modeled in the form of model marts and model warehouses so as to obtain knowledge through various conversions. In addition, Wadhwa and Saxena [53] formulated Decision Knowledge Sharing framework that explains the capability to use shared knowledge as resultant so as to make use of critical decision synchronization. The DKS facilitate sourcing and distribution decisions for critical decision making. The simulation model developed elucidates the flexibility and DKS in supply chains using cost as a performance measure.

Goldberg [57] had presented diverse methods such as citizenbased consensus conference, neighbourhood conversations, and knowledge cafe' sessions for citizen participation processes. The participation of citizens as a part of its routine fluent operations was in the prerogative of its municipality. However, Helen [21] contributed for emergency managers to prepare themselves and respond to emergencies and disasters with a focus on the improvement of their decision making capabilities. The results revealed that information is available for decision making but only few emergency managers were aware of the existence of this information. Similarly, Peter [44] pursued naturalistic decision making. The focus was on decision making capability of how human experts under the constraints of time, pressure and complexity. The study emphasized the use of cognitive task analysis which is generally used in case of NDM as pliable technique of knowledge management in any organization.

On the other hand, Mohammed and Jalal [39] explored the connection between knowledge management and decision making. The impact of knowledge management on decision making was analyzed through the factors like information technology infrastructure, human resource, knowledge sharing and the culture of the organization that had a positive impact on decision making. Subsequently, it revealed that in order to make successful decision, the various indicators of knowledge management needs viable implementation. Furthermore, Nazir and Shah [40] examined the impact on organizational performance through factors of Knowledge Sharing, Participative Decision Making and Transformational Leadership. As far as effective implementation of the goals of organization is concerned, the participation of employees in decision making can likewise help an organization. Apart from this intellectual capital, the transformational leaders play the role of an imperative element for the success of an organization.

However, Riaz \& Khalili [48] studied the moderating role of knowledge management processes in decision making in view of service providing organizations. Doante \& de Pablo [15] examined the mediating effect of KM practices between the relationship of knowledge-oriented leadership and innovation performance. The existence of such a leadership persuade the development and usage of practices of KM process i.e., creation, storage, transfer, and application of knowledge. In addition, the study highlighted the fact that usage of KM practices improves the performance in product innovation.

From the above discussion, one needs to apprehend that the knowledge Management is a stool. Misra [38] resting on three essential legs-People, Process and Technologies. And the decision making framework cannot ignore these essential elements, which forms the intellectual Capital. Though many of the prior studies dealt with the intellectual capital in addition to the other enablers effecting KM performance to access the organizational performance, but very feeble studies have studied its impact on decision making. The knowledge Management process comprising of three essential activities of idea generation, forming knowledge repository and information flow, has mediating role of decision making process. Also a very vital factor i.e. Innovation also has its role in decision making which no doubt has a two way role with knowledge management. Henceforth, in this study the endeavor is to build up a model that analyzes the effect of knowledge management on decision making in e-governance with an apparent affect of its independent variables.

The discussion of the past studies revealed an apparent relationship between intellectual capital, knowledge management and decision making; but there is deficiency of research as far as the communal reference in the field of egovernance is concerned. Henceforth, to study the constructual framework of knowledge management and its moderating effect on human, structural and relational capital on decision-making, it was analysed to address the issue of communal reference in the field of e-governance.

\section{DATABASE AND RESEARCH METHODOLOGY}

The constructs incorporated for the survey were derived from the exhaustive literature reviewed. A set of sixty-four items (statements) were taken up in questionnaire. These observed variables or statements were the instrument to measure human capital, structural capital, relational capital that constitutes latent variables and which may contribute to decision making of the organisation. Apart from these, the three constructs of knowledge management process were identified. These were Idea generation, Knowledge Repository and knowledge dissemination/Information. This is as shown in figure 1. In order to measure the responses, 5-point Likert Scale, ranging from 1 to 5 i.e. "strongly agree" to strongly disagree respectively was used. However, pilot survey was done to improve the questionnaire and then full scale survey was done.

To validate the model, a survey was conducted with 200 administrative and technical staff at different managerial levels, which use the organization, based Knowledge Management Systems in their e-governance tasks. For the purpose of data collection, 270 respondents were contacted through email and in person in the government sectors. But very few responses were received through email. So the respondents were contacted face-to-face in their respective offices. The sample comprised of individuals from different age categories and working in different government organizations in varied projects where knowledge management system prevails.

Hence, the respondents who were well versed with knowledge management system in the government sector were taken for the study. The universe of the study comprised National Capital Region of India (i.e. Delhi, Noida \& Gurgaon); Chandigarh, the Union Territory and the Punjab State. The softwares used for analysis of the data being collected were Statistical Package for Social Sciences (SPSS), version 18.0 and Analysis of Moments Structures (AMOS), version 18.0.

As per the previous discussion, pertaining to knowledge management system and decision making, a framework has been hypothesized which tends to explain the role of intellectual assets and decision making in the light of knowledge management variables. This relationship has been analysed in two parts. Part-I deals with investigation of the impact of intellectual capital on decision making. Here, the relationship of individual factors pertaining to Intellectual Capital on Decision Making has been analysed. 
Subsequently, in the second section of this study, the moderating effects of sub-constructs of KMP have been studied upon the individual factors constituting the intellectual capital.

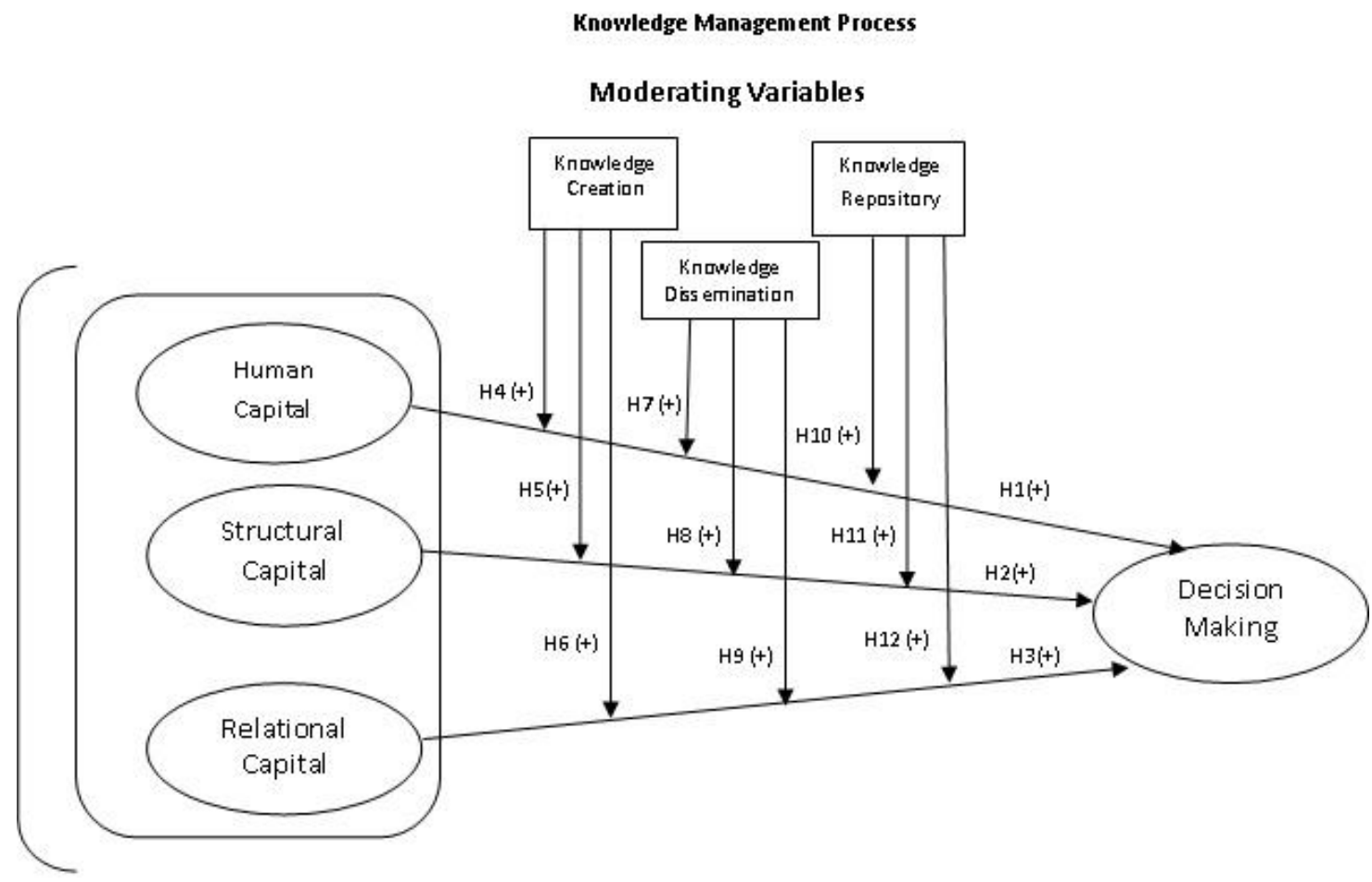

Fig 1: Proposed conceptual model

\section{ANALYSIS AND INTERPRETATION}

\subsection{Hypotheses and Research Model}

The research model proposed (Figure 1) explains the relationship of human capital, structural capital and relational capital with decision making. Though the literature otherwise consider them as the constituents of intellectual capital but in the present study their individual effect on decision making was analyzed. The model exhibits that the sub-constructs of Knowledge Management process, i.e. Knowledge Creation/Idea Generation, Knowledge Repository and Knowledge Dissemination, as moderating variables which may moderate the effect on decision making.

In accordance with the conceptual model been proposed, twelve hypotheses were framed to achieve the objective of the study-

H1: Human Capital of Intellectual capital is positively related with Decision making.

H2: Structural Capital of Intellectual capital is positively related with Decision making.

H3: Relational Capital of Intellectual capital is positively related with Decision making.

H4: Knowledge Creation of the KM Process moderates the relationship of Human Capital with the decision making process.

H5: Knowledge Creation of the KM Process moderates the relationship of Structural Capital with the decision making process.
H6: Knowledge Creation of the KM Process moderates the relationship of Relation Capital and decision making process.

H7: Knowledge Repository of the KM Process moderates the relationship of Human Capital with decision making process.

H8: Knowledge Repository of the KM Process moderates the relationship of Structural Capital with decision making process.

H9: Knowledge Repository of the KM Process moderates the relationship of Relation Capital and decision making process.

H10: Knowledge Dissemination of the KM Process moderates the relationship of Human Capital and decision making process.

H11: Knowledge Dissemination of the KM Process moderates the relationship of Structural Capital and decision making process.

H12: Knowledge Dissemination of the KM Process moderates the relationship of Relation Capital with the decision making process 


\subsection{Validation Measures of Measurement Model}

\subsubsection{Content Validity}

The content validity of the scale needs to be ensured before undergoing the structural equation modeling. Content validity is the manner through which the items/ scale is developed and that ensures the degree of correctness of the claims through its theoretical content i.e. the relevant review of literature.
The Scale developed was based on the review of relevant literature on Decision Making in the light of knowledge management system. An initial set of items was adapted from the existing review of literature where they were reported to be valid and reliable for the constructs that were measured Later on, modifications were made with these items for attaining the desired objective in the study. The content validity was ensured, since these constructs and items thereof have been adapted from the relevant literature.

Table 1. Content Validity

\begin{tabular}{|c|c|c|}
\hline & Constructs & Adapted from \\
\hline \multirow[t]{3}{*}{ Intellectual Capital } & Human Capital & $\begin{array}{l}\text { (Ahmadi[1]; Bontis[6,7]; Cabrita \& Bontis[4];Hsu \& Sabherwal [24]; } \\
\text { Ling[32]; Cahyaningsih et al., [10]; Iman,[25]; Sharabati et al.,[50]; } \\
\text { Gold } \text { et al. [19]) }\end{array}$ \\
\hline & Structural Capital & $\begin{array}{l}\text { (Ahmadi[1]; Ling[32]; Subramaniam \& Youndt[51]; Sharabati et } \\
\text { al.[50]; Iman[25]; Hsu \& Sabherwal[24]; Gold et al.[21]; Reed et } \\
\text { al.[47]) }\end{array}$ \\
\hline & Relational Capital & $\begin{array}{l}\text { (Ahmadi[1]; Ling[32]; Sharabati et al.,[50]; Iman,2014; Subramaniam } \\
\text { \& Youndt [51]; Hsu \& Sabherwal [24]; Gold et al. [21]; Reed et } \\
\text { al.[47]) }\end{array}$ \\
\hline \multirow{4}{*}{$\begin{array}{ll}\text { Knowledge } & \text { Management } \\
\text { Process } & \end{array}$} & Knowledge Creation & (Ling[32]; Gholami et al. [18]; Doante \& de Pablo[15]) \\
\hline & Knowledge Repository & $\begin{array}{l}\text { (Ling[32]; Gholami et al.[18]; Kamran \& Sabir[28] ; Doante \& de } \\
\text { Pablo[15]) }\end{array}$ \\
\hline & Knowledge Dissemination & $\begin{array}{l}\text { (Ling[32]; Gholami et al.[18]; Mohammed \& Jalal[39]; Kamran \& } \\
\text { Sabir, [28]; Goldberg, [57]; Doante \& de Pablo[15] }\end{array}$ \\
\hline & Decision Making & $\begin{array}{l}\text { (Paprika[45]; Bolloju et al.[9]; Wadhwa \& Saxena,[53]; Olzen et } \\
\text { al.[43]; Jane et al. [27]; Mohammed \& Jalal[39]; Riaz \& Khalil [48]; } \\
\text { Nazir \& Shah, [40]; Gold et al.[19]) }\end{array}$ \\
\hline
\end{tabular}

\subsubsection{Fit Indices of Measurement Model}

Confirmatory factor analysis (CFA) was employed to estimate the measurement model. The model fitness is indicated from the observations of confirmatory factor analysis along with

various parameters estimated in measurement model such as item loadings, item measurement errors and factor correlations. In assessment of the model validity, factor loading of each observed variable should be more than 0.60

and those variables which have factor loadings less than this acceptable limit are likely the candidates for deletion [35]. 


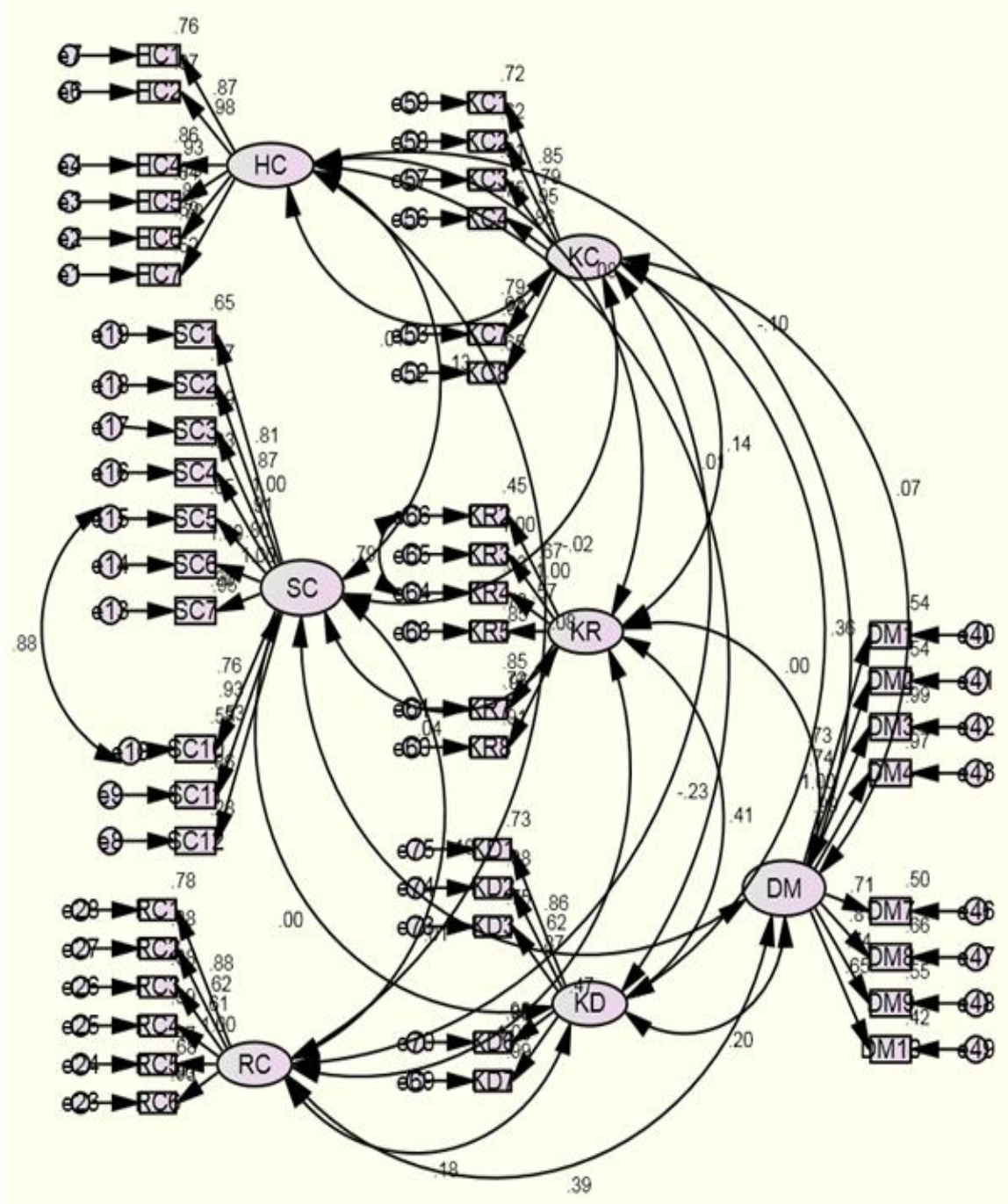

(HC: Human Capital; SC: Structural Capital; RC: Relational Capital; KC: Knowledge Creation; KR: Knowledge Repository; KD: Knowledge Dissemination; DM: Decision Making )

Fig 2: Measurement model of effect on decision making

The initial structure of the model consisting of sixty four items needed refinement in the model. In the measurement model, variables HC3, SC8, SC9, RC7, RC8, RC9, DM5, DM 6, DM 11, DM 12, KC 5, KC 6, KR 1, KR 6, KD 4, KD 5, KD 8 belonging to different constructs exhibited low factor loadings. Hence, in order to improve model fitness, these variables were deleted from the formulated scale. In the final model forty seven items were retained for the seven dimensions taken up for study. This is apparent in figure 2 .

For the assessment of measurement model, various indices were calculated which ensured the model's fitness. The indices included here are chi-square/degree of freedom, Comparative Fit Index (CFI), Tucker-Lewis Index (TLI), Incremental Fit Index (IFI), Root Mean Square Error of Approximation (RMSEA) and Root Mean Square Residual (RMR). The fitness indices given in Table 2 were calculated after deleting the variables with low factor loadings and even after making some modifications in the model by correlating the error terms. The multiple fit indexes which indicate fitness of the model to data are given in the table 2 . The goodness-offit of the model is 4.271(chi square/degree of freedom) and it is less than 5 as recommended by Hoyle(1995). The Goodness-of-fit was measured through the indices i.e. Comparative Fit Index (CFI), Tucker- Lewis Index (TLI) and Incremental Fit Index (IFI) that had the values 0.926, 0.901, 0.926 and were in the minimum acceptable range [17].

The value of Root Mean Square Residual (RMR) is 0.037 and Root Mean Square Error of Approximation (RMSEA) is 0.0632 for the model that were in the range of their respective limits i.e. below 0.05 and less than 0.10 as suggested by Fadlelmula [17]. This ensured the good fit of the model with the data. 
Table 2. Fit indices of measurement model

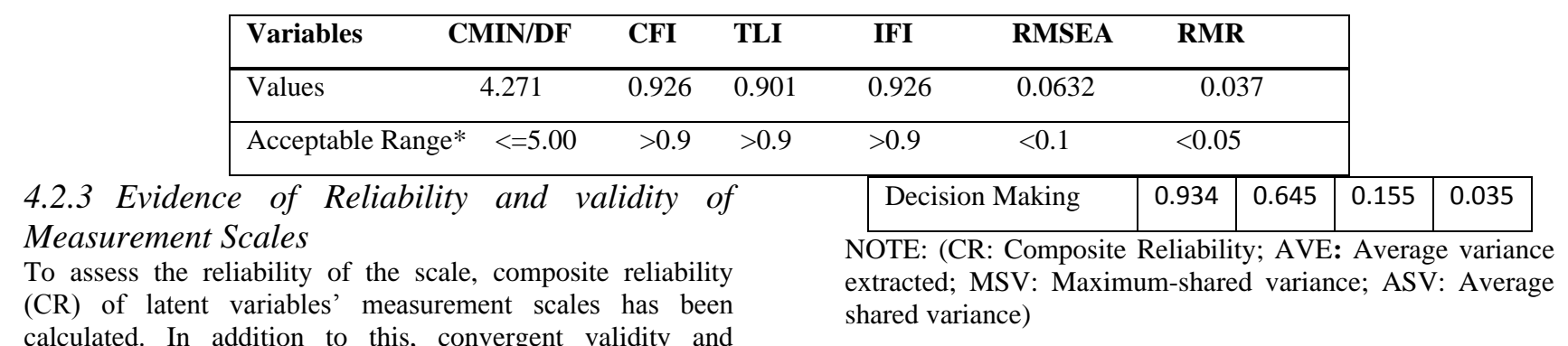
discriminant validity have been analyzed to access construct validity of the scales. Composite Reliability measures the overall reliability of the scale that constitute heterogeneous but similar items while the construct validity assesses the adequacy of the theoretical construct of the scale on the basis of test scores.

Table-3 illustrates the reliability and validity results. It depicts value for Composite Reliability (CR) for the constructs and here it is observed that for each construct it is greater than 0.70 that corresponds to the minimum acceptable value [35] Hence, it ensures the scale to be reliable.

Convergent validity is the degree to which several attempts to measure the same construct are in agreement and hence converge on a single construct. The AVE and CR have been used to ensure the convergent validity of each construct. The recommended range of AVE, as suggested [35], is greater than or equal to 0.5 since the adequate measure of convergent validity should have error variance less than 50 percent. In addition, for each construct the composite reliability (CR) needs to be greater than AVE. Both of these results were observed to be satisfactory as shown in table 3 .

Table 3. Reliability and Validity Analysis

\begin{tabular}{|l|l|l|l|l|}
\hline Constructs & CR & AVE & MSV & ASV \\
\hline Human Capital & 0.939 & 0.723 & 0.017 & 0.007 \\
\hline Structural Capital & 0.947 & 0.750 & 0.031 & 0.008 \\
\hline Relational Capital & 0.916 & 0.654 & 0.217 & 0.083 \\
\hline Knowledge Creation & 0.936 & 0.712 & 0.132 & 0.035 \\
\hline $\begin{array}{l}\text { Knowledge } \\
\text { Repository }\end{array}$ & 0.927 & 0.685 & 0.217 & 0.068 \\
\hline $\begin{array}{l}\text { Knowledge } \\
\text { Dissemination }\end{array}$ & 0.937 & 0.751 & 0.165 & 0.062 \\
\hline
\end{tabular}

Table 4. Fit Indices of structural model

\begin{tabular}{|lcccccc|}
\hline Variables & CMIN/DF & CFI & TLI & IFI & RMSEA & RMSR \\
\hline Values & 4.184 & 0.905 & 0.901 & 0.906 & 0.055 & 0.039 \\
\hline Acceptable Range* & $<=5.00$ & $>0.9$ & $>0.9$ & $>0.9$ & $<0.1$ & $<0.05$ \\
\hline * Fadlelmula[17]; Hoyle[22] ) & & & & &
\end{tabular}




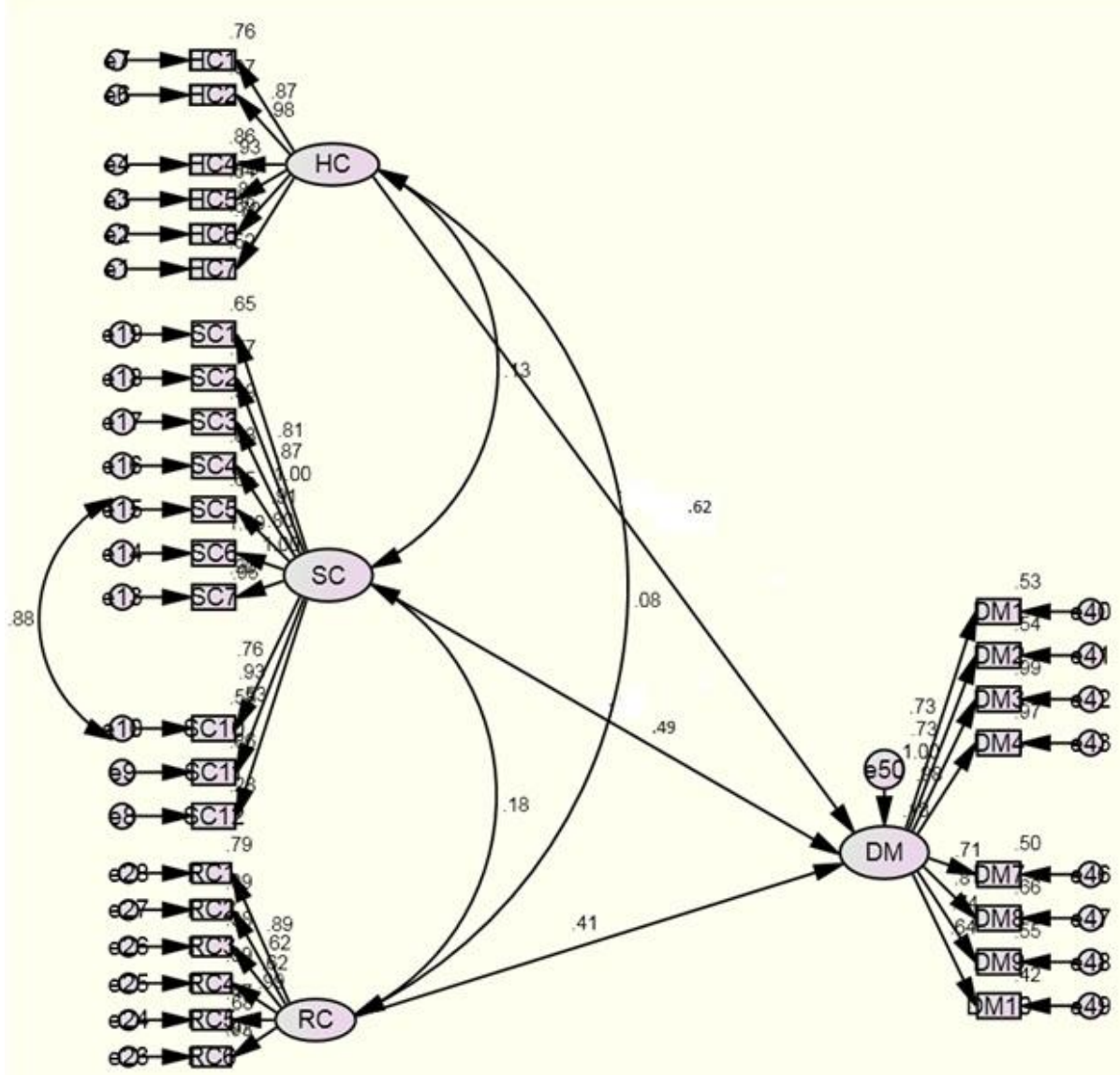

(HC: Human Capital; SC: Structural Capital; RC: Relational Capital; KC: Knowledge Creation; KR: Knowledge Repository; KD: Knowledge Dissemination; DM: Decision Making )

Fig 3: Structured Equation Modeling

Table 5: Standardized Regression Weights of the Structural Model

\begin{tabular}{|l|l|l|l|}
\hline $\begin{array}{l}\text { Hypotheses: } \\
\text { Causal Path }\end{array}$ & $\begin{array}{l}\text { Standardized } \\
\text { Regression } \\
\text { Weights }\end{array}$ & t value & Decision \\
\hline H1: DM <---HC & .62 & $10.489 * * *$ & Accepted \\
H2: DM <---SC & .49 & $4.267 * * *$ & Accepted \\
H3: DM<---RC & .41 & $4.904 * * *$ & Accepted \\
\hline
\end{tabular}

Note: $* * * \mathbf{p}<0.001$

NOTE: (DM: Decision Making, HC: Human Capital, SC: Structural Capital, $\boldsymbol{R C}$ : Relational Capital)

The results provide the evidence for the suppositions made. The observations made from the results of the path coefficients of the model are as given below:

$>$ The human capital has a positive relationship with decision making" with beta value of $\left(\beta=0.62, R^{2}=\right.$ 0.3844 ). The hypothesis $\mathrm{H} 1$ was supported at 0.001 , level of significance.

> "Structural capital" has statistically significant relationship with 'decision making' with beta value $\left(\beta=0.49, R^{2}=0.2401\right)$ at 0.001 level of significance and hence provides a support for hypothesis $\mathrm{H} 2$

$>$ "Relational Capital" has statistically significant relationship with 'decision making' at 0.001 level of significance, with beta value of $\left(\beta=0.41, R^{2}=0.1681\right)$ thus supporting the hypothesis $\mathrm{H} 3$.

From the table 5, it is evident that it is the Human Capital which is affecting the Decision making the most, then followed by Structural $\operatorname{Capital}(\beta=0.49)$ and Relational $\operatorname{Capital}(\beta=0.41)$. The reason for these observations may be that the actual decision makers are the individuals/intellectuals who comprise the set of Human Capital. Since their decision is based upon the decision support system which is better if the structural capital is advance and supportive. Henceforth, the decision making involves rationality, and more advance decision support system will lead to more accuracy and better productivity.

The effect of Relational Capital on Decision Making is low in comparison to these constructs which may be because of the fact that the relationship ties only act as the coordinating elements to provide decision efficacy and not the actual data providers to support the rationale of decision making.

\section{MODERATING ROLE OF KNOWLEDGE MANAGEMENT PROCESS ON DECISION MAKING}

In order to examine the role of knowledge management process on decision making the moderation was checked for three sub-constructs which figure out the knowledge management process. These constructs were Knowledge Creation, Knowledge Repository and Knowledge 
Dissemination. Individually, the interaction moderation of each of these respective constructs were measured after interacting them with three constructs of human Capital, Structural Capital, and Relational Capital which were acting as independent variables. Henceforth, the moderation was examined by taking decision making as dependent variable.

\subsection{Moderating Effect of Knowledge \\ Creation}

Table 6 shows the interaction effects of Knowledge Creation and factors of Intellectual Capital i.e., Human Capital, Structural Capital, and Relational Capital on Decision Making in e-governance systems.

Table 6: Summary of Moderation Effect of Knowledge Creation

\begin{tabular}{|l|l|l|l|l|}
\hline $\begin{array}{l}\text { Moderating } \\
\text { Variable }\end{array}$ & $\begin{array}{l}\boldsymbol{\beta} \\
\text { Value }\end{array}$ & $\mathbf{p}$ Value & Remarks & Rank \\
\hline HC x KC & 0.087 & $1 \%$ & $\begin{array}{l}\text { Significant } \\
\text { Moderation }\end{array}$ & 2 \\
\hline SC x KC & 0.03 & $1 \%$ & $\begin{array}{l}\text { Significant } \\
\text { Moderation }\end{array}$ & 3 \\
\hline RC x KC & 0.139 & $1 \%$ & $\begin{array}{l}\text { Significant } \\
\text { Moderation }\end{array}$ & 1 \\
\hline
\end{tabular}

The table 6 shows that the knowledge creation moderates the relationship between all the constructs (human capital, structural and relational capital) and decision making having interaction term beta values as $0.087,0.030$ and 0.139 respectively all at $1 \%$ level of significance.

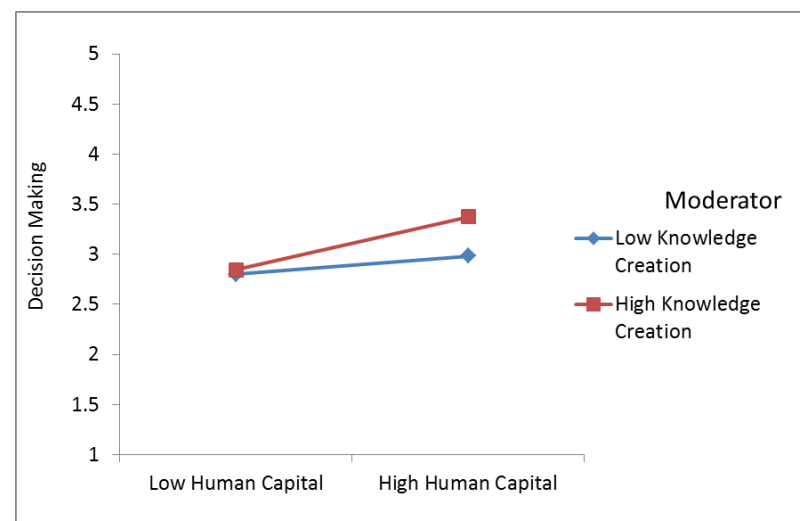

Fig 4: Moderating Role of Knowledge Creation on decision making in case of Human Capital

The figure 4 provides the evidence that the slope of high knowledge creation is more than low knowledge creation. This clearly shows that human capital leads to decision making in the light of knowledge creation. This provides support for hypothesis H4. However, the moderation effect of knowledge creation between human capital and decision making clearly indicates that where human capital is high coupled with high knowledge creation in e-governance systems, the decision making abilities are enhanced in the selected government organizations taken in the present study. On the contrary, the low human capital even with high knowledge creation is ineffective towards decision making process.
Furthermore, low human capital with low knowledge creation generates similar effect with high knowledge creation towards decision making in e-governance systems. In addition to this, high human capital with low knowledge creation is not as effective towards decision making in comparison to organizations having high knowledge creation with high human capital.

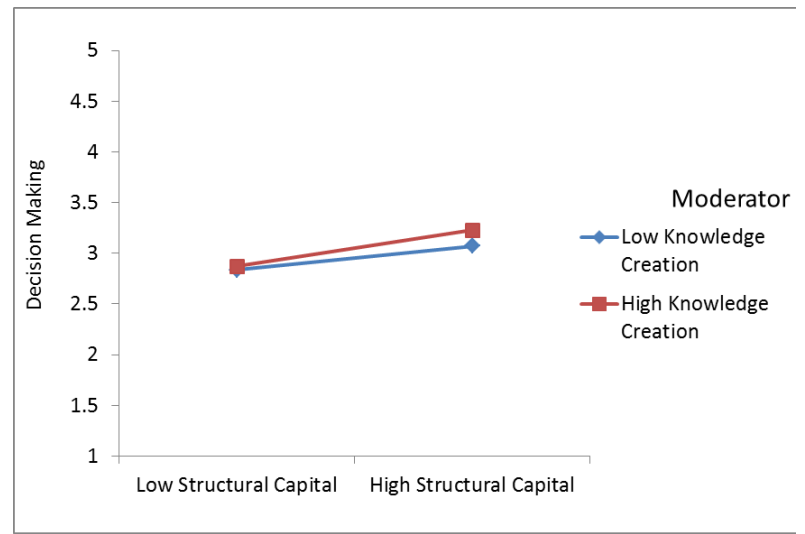

\section{Fig 5: Moderating Role of Knowledge Creation on} decision making in case of Structural Capital

In figure 5, knowledge creation is found to moderate the relationship between structural capital and decision making. Here the structural capital leads to decision making in the light of knowledge capital. Thus it also supports for the acceptance of the hypothesis H5.

However, the moderation effect of knowledge creation between structural capital and decision making clearly indicates that low structural capital even with high knowledge creation remains ineffective towards decision making process in comparison to low knowledge creation. Also where structural capital is high coupled with high knowledge creation in e-governance systems, the decision making abilities are inadequately enhanced in comparison to low knowledge creation having high structural capital, in the selected government organizations taken in the present study.

In figure 6 it is revealed that knowledge creation moderates the relationship between relational capital and decision making, since the slope of high knowledge creation is more than low knowledge creation. Hence, it supports the hypothesis H6. Hence high relational capital combined with high knowledge creation leads to good decision making. However, the moderation effect of knowledge creation between relation capital and decision making clearly indicates that where relational capital is high coupled with high knowledge creation in e-governance systems, the decision making abilities are enhanced in the selected government organizations taken in the present study. On the contrary, the low relational capital even with high knowledge creation is ineffective towards decision making process and generates similar effect in case of low relational capital with low knowledge creation.

Moreover, the figure 6 clearly highlights that unlike structural capital and human capital, the interrelationships within organizations leads towards acceptance of knowledge management practices in a better way, thus synergizing the process of decision making. 


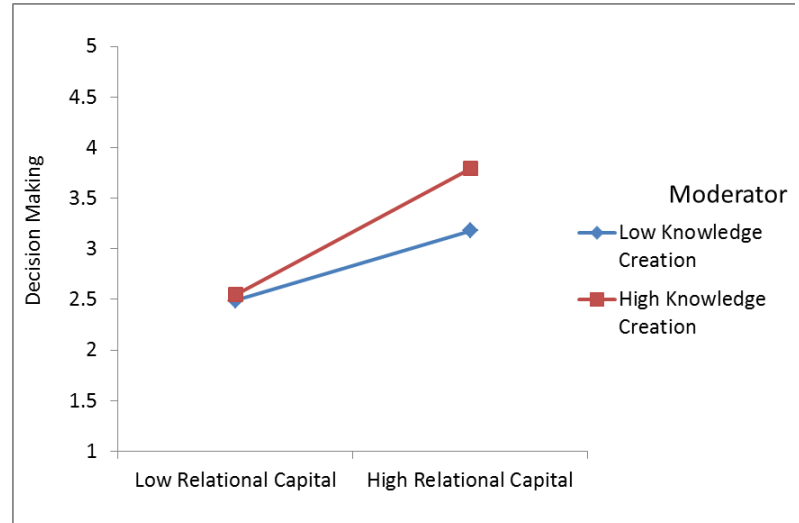

Fig 6: Moderating Role of Knowledge Creation on decision making in case of Relational Capital

Knowledge Creation significantly moderates the effect with respect to all the variables. However, the moderation effect of knowledge creation in terms of its hierarchy of moderation is summarized in table 6. Hence the results of interaction moderation corroborates with those of categorical moderation which shows that the decision making is significantly moderated by knowledge creation in case of relational capital in comparison to other capitals.

The above discussion clearly indicates that the interaction effect shows better moderating results with the relational capital and human capital rather than the structural capital. The plausible explanation for this could be that in case of implementation of knowledge creation, it is the relationship ties which are more important as because the creation becomes better when there is collaboration between the knowledge creators. Since the intellectuals are the actual creators of the knowledge, hence the human capital also moderates the relation actively as compared to the structural capital which is actually only acting as a support system to facilitate the creation and hence decision making. From these observations it can be concluded that it is the individual who creates the knowledge and not the physical structure of the system. The moderation becomes higher because final decision making is done by the human resources and not by the structural components, as they only act as support to the decision making.

\subsection{Moderating Effect of Knowledge \\ Repository}

Table 7 shows the interaction effects of Knowledge Repository and constructs i.e., Human Capital, Structural Capital, and Relational Capital on Decision Making in egovernance systems. The knowledge repository moderates the relationship between all the constructs (human capital, structural and relational capital) and decision making having interaction term beta values as $0.065,0.010$ and 0.016 respectively all at $1 \%$ level of significance. This is as shown in table 7.
Table 7: Summary of Moderation Effect of Knowledge Repository

\begin{tabular}{|l|l|l|l|l|}
\hline $\begin{array}{l}\text { Moderating } \\
\text { Variable }\end{array}$ & $\begin{array}{l}\text { B } \\
\text { Value }\end{array}$ & $\mathbf{p}$ Value & Remarks & Rank \\
\hline HC x KR & 0.065 & $1 \%$ & $\begin{array}{l}\text { Significant } \\
\text { Moderation }\end{array}$ & 1 \\
\hline SC x KR & 0.010 & $1 \%$ & $\begin{array}{l}\text { Significant } \\
\text { Moderation }\end{array}$ & 3 \\
\hline RC x KR & 0.016 & $1 \%$ & $\begin{array}{l}\text { Significant } \\
\text { Moderation }\end{array}$ & 2 \\
\hline
\end{tabular}

The figure 7 provides the evidence that the slope of high knowledge repository is more than low knowledge repository. This clearly shows that human capital leads to decision making in the light of knowledge repository. This leads to the acceptance of the hypothesis $\mathrm{H} 7$.

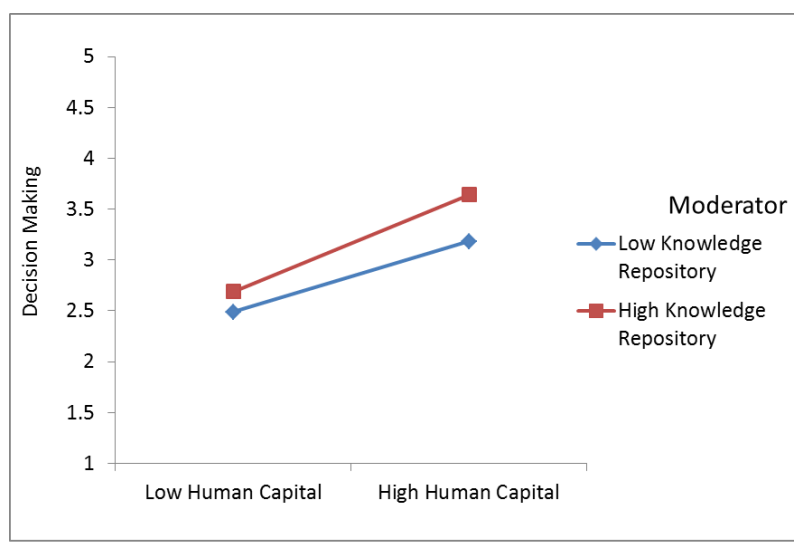

Fig 7: Moderating Role of Knowledge Repository on decision making in case of Human Capital

In this case, the moderation effect of knowledge repository between human capital and decision making clearly indicates that when human capital is high coupled with high knowledge repository in e-governance systems, the decision making abilities are enhanced in the selected government organizations taken in the present study. Also, high knowledge repository with the low human capital is effective in enhancing the decision making process in comparison to low knowledge repository. However, high human capital with low knowledge repository is comparatively effective towards decision making in comparison to organizations having low knowledge repository with low human capital. But, it lowers the decision making in comparison to high knowledge repository.

The figure 8 provides the evidence that the slope of high knowledge repository is more than low knowledge repository. This clearly shows that structural capital leads to decision making in the light of knowledge repository. This leads to the acceptance of the hypothesis H8. 


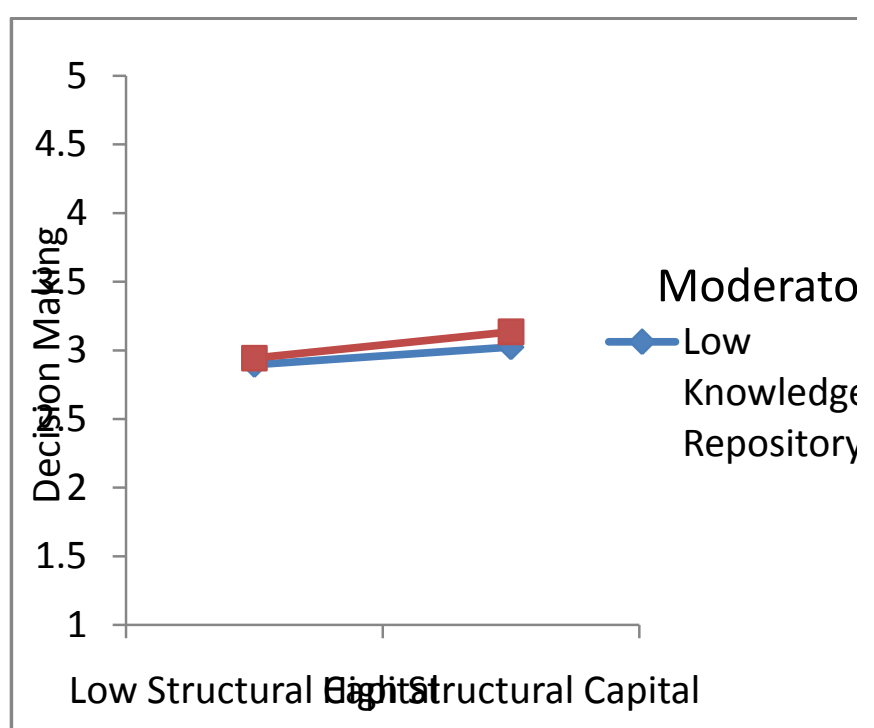

Fig 8: Moderating Role of Knowledge Repository on decision making in case of Structural Capital

However, the moderation effect of knowledge creation between structural capital and decision making clearly indicates that where structural capital is high coupled with high knowledge repository in e-governance systems, the decision making abilities are enhanced in the selected government organizations. However, the change in effect on decision making is very less if the knowledge repository is low On the contrary, the low structural capital even with high knowledge creation remains ineffective towards decision making process. Furthermore, low structural capital with low knowledge creation generates similar effect with high knowledge repository towards decision making in egovernance systems. In addition to this, high structural capital with low knowledge repository is not as effective towards decision making in comparison to organizations having high knowledge repository with high structural capital.

Also figure 9 provides the evidence that the slope of high knowledge repository is more than low knowledge repository. This clearly shows that relational capital leads to decision making in the light of knowledge repository. In other words it can also be said that if knowledge repository is low then despite the fact that there is high relational capital, the decision making will be low. Hence the hypothesis H9 is accepted.

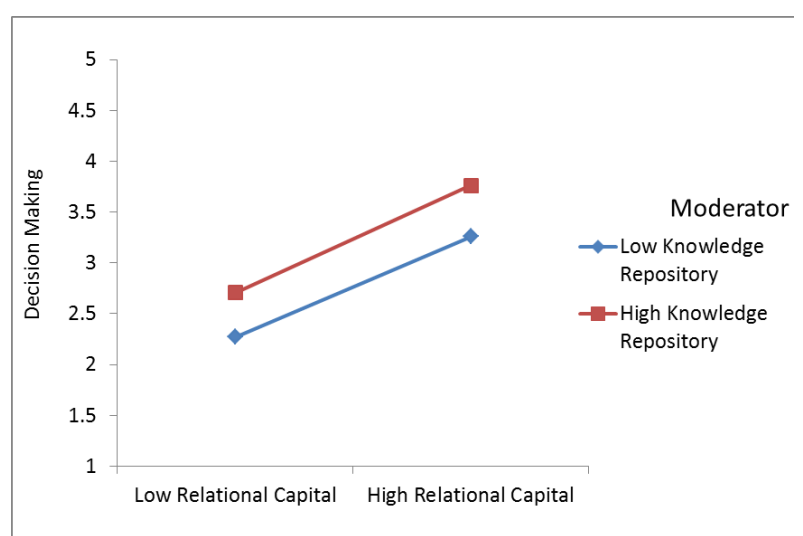

Fig 9: Moderating Role of Knowledge Repository on decision making in case of Relational Capital
However, the moderation effect of knowledge repository between relational capital and decision making clearly indicates that where relational capital is high coupled with high knowledge repository in e-governance systems, the decision making abilities are enhanced in the selected government organizations taken in the present study. Also, the low relational capital with high knowledge repository is effective towards decision making process.

Furthermore, low relational capital with low knowledge repository does not generates similar effect with high knowledge repository towards decision making in egovernance systems. This clearly show that the creation of knowledge repository has more positive effect on decision making when it is combined with human capital then followed by relational capital and structural capital. Thus the knowledge residing in the brains within the government organization needs to be efficiently stored for making future directions.

This is unlike in case of knowledge creattion as moderating variable where relational capital has the upper hand in decision making, which may be explained in a manner that the relationship ties act as coordinators in the process of decisionmaking, since cordination is the essence of management . Hence, more positive effect of knowledge management on decision making is explained herein.

\subsection{Moderating Effect of Knowledge Dissemination}

Table 8 shows the interaction effects of Knowledge Dissemination and constructs i.e. Human Capital, Structural Capital, and Relational Capital on Decision Making in egovernance systems. The table 8 shows that the knowledge creation moderates the relationship between all the constructs (human capital, structural and relational capital) and decision making having interaction term beta values as $0.145,0.093$ and 0.024 respectively all at $1 \%$ level of significance.

Table 8: Summary of Moderation Effect of Knowledge Dissemination

\begin{tabular}{|l|l|l|l|l|}
\hline $\begin{array}{l}\text { Moderating } \\
\text { Variable }\end{array}$ & $\boldsymbol{\beta}$ Value & $\mathbf{p}$ Value & Remarks & Rank \\
\hline $\mathrm{HC} \times \mathrm{KD}$ & 0.145 & $1 \%$ & $\begin{array}{l}\text { Significant } \\
\text { Moderation }\end{array}$ & 1 \\
\hline $\mathrm{SC} \times \mathrm{KD}$ & 0.093 & $1 \%$ & $\begin{array}{l}\text { Significant } \\
\text { Moderation }\end{array}$ & 2 \\
\hline $\mathrm{RC} \times \mathrm{KD}$ & 0.024 & $1 \%$ & $\begin{array}{l}\text { Significant } \\
\text { Moderation }\end{array}$ & 3 \\
\hline
\end{tabular}

The figure 10 provides the evidence that the slope of high knowledge dissemination is more than low knowledge dissemination. This provides support for hypothesis $\mathrm{H}_{10}$ .However, the moderation effect of knowledge dissemination between human capital and decision making indicates that where human capital is high coupled with high knowledge dissemination in e-governance systems, the decision making abilities are enhanced in the selected government organizations taken in the present study.

On the contrary, the high human capital with low knowledge dissemination lowers the effect of decision making process in e-governance systems. Furthermore, low human capital with low knowledge dissemination generates almost similar effect 
with high knowledge dissemination towards decision making in e-governance systems.

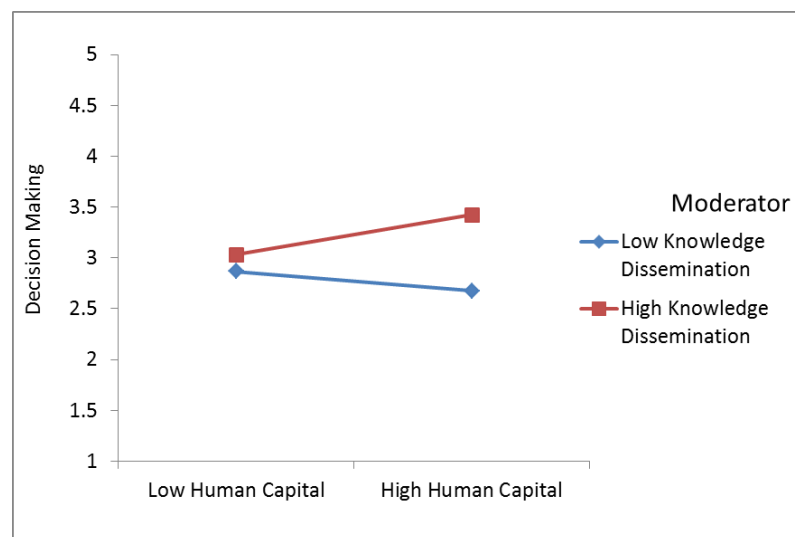

Fig 10: Moderating Role of Knowledge Dissemination on decision making in case of Human Capital

The figure 11 provides the evidence that the slope of high knowledge dissemination is high than low knowledge dissemination leading to the acceptance of the hypothesis H11.

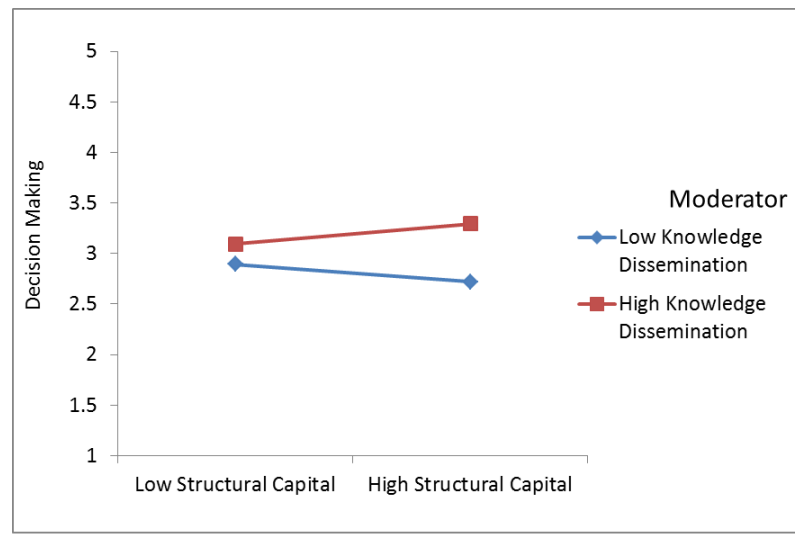

Fig 11: Moderating Role of Knowledge Dissemination on decision making in case of Structural Capital

In this case, the moderation effect of knowledge dissemination between structural capital and decision making indicates that where structural capital is high coupled with high knowledge dissemination in e-governance systems, the decision making abilities are enhanced in the selected government organizations taken in the present study.

On the contrary, the high structural capital with low knowledge dissemination lowers the effective decision making in e-governance systems. Furthermore, low structural capital with low knowledge dissemination generates almost similar effect with high knowledge dissemination towards decision making in e-governance systems. Hence, its concluded that if knowledge dissemination is low then despite the fact that there is high structural capital, the decision making will be low.

Also figure 12 provides the evidence that the slope of high knowledge dissemination is more than low knowledge dissemination. This clearly shows that relational capital leads to decision making in the light of knowledge dissemination and hence accepting the hypothesis H12. In this case, the moderation effect of knowledge dissemination between relational capital and decision making indicates that where relational capital is high coupled with high knowledge dissemination in e-governance systems, the decision making abilities are enhanced in the selected government organizations taken in the present study.

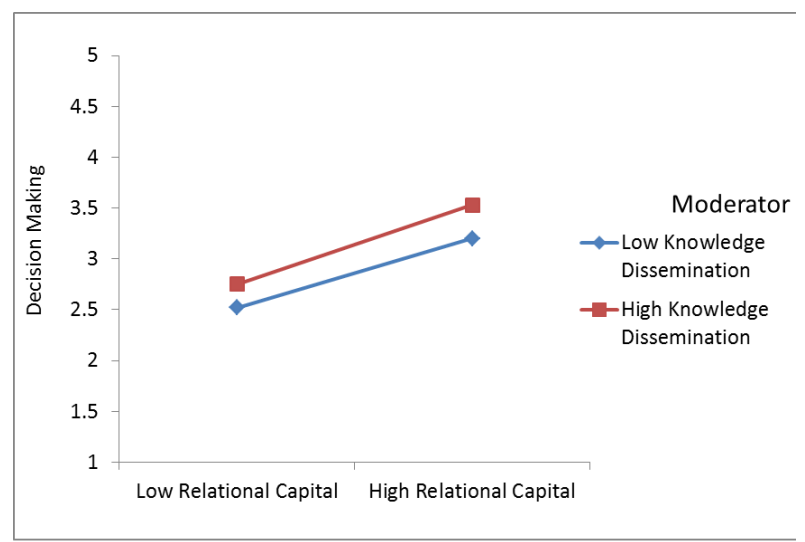

Fig 12: Moderating Role of Knowledge Dissemination on decision making in case of Relational Capital

On the contrary, the high relational capital with low knowledge dissemination does not lower the effective decision making in e-governance systems but is definitely low in comparison with high knowledge dissemination. Furthermore, low relational capital with low knowledge dissemination generates minor effect towards decision making in e-governance systems with high knowledge dissemination. However, high relational capital with low knowledge dissemination is not as effective towards decision making in comparison to organizations having high knowledge dissemination with high relational capital

The above discussion clearly indicates that the interaction effect shows better moderating results with the human capital and structural capital rather than the relational capital. This is unlike the case of knowledge creation and knowledge repository where structural capital has the least role to play for good decision making. These findings may reveal that it is through individuals that the flow of knowledge will take place. And the technology has to play a pivotal role in the dissemination or sharing of knowledge among the individuals. This definitely will enhance the decision making in egovernance systems with more accuracy and efficiency.

\section{CONCLUSION AND IMPLICATIONS}

The study focused upon the interactive role of human capital, relational capital and structural capital (collectively known as intellectual capital) and knowledge management practices (includes knowledge creation, knowledge repository and knowledge dissemination) in decision making of the organization. This research provides a linkage between the interaction of intellectual capital, knowledge management practices and its influences upon the decision-making in the organizations.

This research may help in drawing conclusions relevant to practitioners in government organizations. First, the SEM analysis significantly proves that the human capital, structural capital and relational capital have positive relationship with decision making. Further, from the results of interaction analysis it was found that in case of knowledge creation the moderating role is maximum of relational capital followed by human capital and then structural capital, which is clear indication of the fact that without having collaborations and the intellectuals in the organization mere structure will not enhance the process of creation, as it will only possible with 
the support of culture of sharing of knowledge among the intellectuals. In case of knowledge repository again it is the intellectuals within the organization i.e. the human capital and their relationship commitment which acts as a strong moderators and the structural capital here acts as a supporting factor. Whereas in the case of knowledge dissemination, the chief moderator is the human capital, then followed by structural capital, and finally leading towards relational capital. The obvious reason here is that the intellectuals who create the knowledge can only disseminate it with the help of proper structural formats and not without them.

By analyzing the above observations it can be concluded that in all the three significant activities i.e. Knowledge creation, knowledge repository and dissemination, it is human capital which act as key moderator. This fact connotes the findings that the total success of knowledge management processes in the organization is not possible without the support of individuals/intellectuals working within. And the structure and the system are the support activities and the only value addition is made through the creativity of the individuals within the organization which no doubt is enhanced if they share and collaborate.

Consequently, the findings of the present study have practical contributions to the government organizations in the field of $\mathrm{KM}$ implementation. The findings may serve as a reference for government organization in the implementation of effective KM system in their work culture. The organizations have to maintain efficient human capital being the source of knowledge for the organization, which will in turn improve the decision making. Further, it is necessary to maintain a cordial or interactive relationship amongst all the members of the organization for efficient decision making. To add upon, it can be said that knowledge creation, knowledge repository and knowledge dissemination are vital factors which will enhance the efficacy of decision within the organizations.

\section{REFERENCES}

[1] Ahmadi, A.A., Ahmadi, F. and Shakeri, S. 2013. The survey of relationship between Intellectual capital (IC) and Organizational performance (OP) within the National Iranian South Oil Company. European journal of Business Management, 1(1), 12-28

[2] Asoh, D., Belardo, S., and Neilson, R. 2002.Knowledge management: issues, challenges and opportunities for governments in the new economy. In System Sciences, 2002. Proceedings of the 35th Annual Hawaii International Conference IEEE, 1745-1754.

[3] Andreas Schroeder David Pauleen Sid Huff. 2012. KM governance: the mechanisms for guiding and controlling KM programs. Journal of Knowledge Management. 16(1), 3-21

[4] Bontis , N.and Cabrita , M.R. 2008. Intellectual Capital \&Business Performance InThe Portuguese Banking Industry, Int. J. Technology Management, 43, 212-228.

[5] Bontis, N. 2001. Assessing knowledge assets: a review of the models used to measure intellectual capital. International Journal of Management Reviews, 3, 41-61.

[6] Bontis, N. 2002a. Intellectual capital: an exploratory study that develops measures and models. In C.W. Choo, N. Bontis (Eds.). The Strategic Management of IntellectualCapital and Organizational Knowledge. NY: Oxford University Press.
[7] Bontis, N. 2002b. Managing organizational knowledge by diagnosing intellectual capital: framing and advancing the state of the field. In C.W. Choo, N. Bontis (Eds.).The Strategic Management of Intellectual Capital and Organizational Knowledge.NY: Oxford University Press

[8] Boulesnane, S. and Bouzidi, L., 2013. The mediating role of information technology in the decision-making context. Journal of Enterprise Information Management, 26(4),.387-399. 61-iinov-dm-km

[9] Bolloju, N., Khalifa, M. and Turban, E., 2002. Integrating knowledge management into enterprise environments for the next generation decision support. Decision Support Systems, 33(2), pp.163-176.

[10] Cahyaningsih, E., Sensuse, D. I., \& Sari, W. P. 2015, November. Critical success factor of knowledge management implementation in government human capital management: A mixed method. In Information Technology Systems and Innovation (ICITSI), 2015 International Conference on (1-6). IEEE.

[11] Casalo, L.V., Flavian,C. and Guinaliu, M. 2008. 'The role of satisfaction and website usability in developing customer loyalty and positive word of mouth in the ebanking services', The International Journal of Bank Marketing, 26(6). 399-417.

[12] Castellanos, O. F., \& Torres, L. M. 2010, July. Technology intelligence: Methods and capabilities for generation of knowledge and decision making. In Technology Management for Global Economic Growth (PICMET), 2010 Proceedings of PICMET'10: (1-9). IEEE.

[13] Darroch,J. 2005. Knowledge management, innovation and firm performance. Journal of Knowledge Management, 9(3), 101-115.

[14] Devendra D. Potnis, 2010. Measuring e-Governance as an innovation in the public sector. Government Information Quarterly, 27, 41--48.

[15] Donate, M. J., \& de Pablo, J. D. S. 2015. The role of knowledge-oriented leadership in knowledge management practices and innovation. Journal of Business Research, 68(2), 360-370.

[16] Fidel, P., Schlesinger, W., \& Cervera, A. 2015. Collaborating to innovate: Effects on customer knowledge management and performance. Journal of Business Research, 68(7), 1426-1428.

[17] Fadlelmula, F. K. 2011. Assessing Power of Structural Equation Modeling Studies: A Meta-Analysis', Education Research Journal, 1(3), 37-42.

[18] Gholami, M. H., Asli, M. N., Nazari-Shirkouhi, S., \& Noruzy, A. 2013. Investigating the influence of knowledge management practices on organizational performance: an empirical study. Acta Polytechnica Hungarica, 10(2), 205-216.

[19] Gold, A. H., Malhotra, A. and Segars, A. (2001) 'Knowledge management: An organizational capabilities perspective', Journal of Management Information Systems, 18(1), 185-241.

[20] Gloet, M., \& Samson, D. 2013, January. Knowledge management to support systematic innovation capability. 
In System Sciences (HICSS), 2013 46th Hawaii International Conference on (3685-3694). IEEE.

[21] Helen Sinclair Emma E.H. Doyle David M. Johnston Douglas Paton. 2012.Decision-making training in local government emergency management", International Journal of Emergency Services, 1(2).

[22] Hoyle, R.H. 1995. Structural Equation Modeling: Concepts, Issues, and Application, Sage Publications.

[23] Hung. 2010. Knowledge as a facilitator for enhancing innovation performance through total quality management, Total Quality Management, 21(4), 425438.

[24] Hsu, I. and Sabherwal, R., 2012. Relationship between intellectual capital and knowledge management: an empirical investigation. Decision Sciences, 43(3), 489524.

[25] Iman Salemi and Lange Roodi. 2014. The effect of the knowledge management and intellectual capital on organizational performance in state banks of Rasht. Indian Journal of Fundamental and Applied Life Sciences, 4(S1), 1393-1404.

[26] Jafari, S. M., \& Ramalingam, M. S. T. 2014, June. The effect of knowledge management practices on employees' innovative performance. In Proceedings of the 2nd International Conference on Innovation and Entrepreneurship: ICIE 2014 (112). Academic Conferences Limited.

[27] Jane McKenzie, Christine van, Winkelen Sindy Grewal,.2011.Developing organisational decisionmaking capability: a knowledge manager's guide", Journal of Knowledge Management, 15(3), 403 - 421

[28] Kamran, M. R., \& Sabir, F. 2012. Knowledge management a gate way to analyze effective organizational performance. Far East Journal of Marketing and Management, 2(5), 53-68.

[29] Lakshman, C., 2014. Leveraging human capital through performance management process: the role of leadership in the USA, France and India. The International Journal of Human Resource Management, 25(10), 1351-1372.

[30] Laith Ali Al-Hakim \& Shahizan Hassan .2016.Core requirements of knowledge management implementation, innovation and organizational performance, Journal of Business Economics and Management, 17:1, 109-124,

[31] Liao, S. and $\mathrm{Wu}$, C. 2010. System perspective of knowledge management, organizational learning, and organizational innovation. Expert Systems with Applications, 37,1096-1103.

[32] Ling, Y.H., 2013. The influence of intellectual capital on organizational performance-Knowledge management as moderator. Asia Pacific Journal of Management, 30(3), 937-964.

[33] M. Subramaniam and M. A. Youndt, 2005.The influence of intellectual capital on the types of innovative capabilities," Acad. Manage. J., 48, (3) 450-463.

[34] M. A. Youndt, M. Subramaniam, and S. A. Snell. 2004. Intellectual capital profiles: An examination of investments and returns," J. Manage. Stud., 41(2), 335361.
[35] Malhotra, N.K. and Dash, S. 2010. Marketing Research: An Applied Orientation, Pearson Education India, Edition $6^{\text {th. }}$

[36] Manlio Del Giudice Maria Rosaria Della Peruta. 2016.The impact of IT-based knowledge management systems on internal venturing and innovation: a structural equation modeling approach to corporate performance", Journal of Knowledge Management, 20(3), 484 - 498

[37] Michal Goldberg Edna Pasher Maya Levin-Sagi. .2006.Citizen participation in decision-making processes: knowledge sharing in knowledge cities", Journal of Knowledge Management, 10 (5), 92 - 98

[38] Misra, D. C. 2007, January. Ten guiding principles for knowledge management in e-government in developing countries. In first international conference on knowledge management for productivity and competitiveness.

[39] Mohammed, W., \& Jalal, A. 2011. The influence of knowledge management system (KMS) on enhancing decision making process (DMP). International Journal of Business and Management, 6(8), 216-229

[40] Nazir, T., \& Shah, S. F. H.2014. Mediating effect of knowledge sharing between participative decision making, transformational leadership and organization performance. Journal of Management Info, 1(1), 1-12.

[41] Nowacki, R., \& Bachnik, K..2016. Innovations within knowledge management. Journal of Business Research, 69(5), 1577-1581.

[42] Otto, W. F. 2006. Making Decisions Using Knowledge Management. Presented at the North East National Collegiate Honors Council Conference, in Pittsburgh, Pa, April 6-9, 2006 http://www.neumann.edu/about/publications/NeumannB usinessReview/journal/review_2007/knowledge_mgt.pdf

[43] Ozlen, K., Handzic, M., \& Durmic, N. 2014. Empirical Study of KMS Impact on Decision Support. Eurasian Journal of Business and Economics, 7(13), 133-144.

[44] Peter Meso Marvin D. Troutt Justyna Rudnicka, 2002.A review of naturalistic decision making research with some implications for knowledge management. Journal of Knowledge Management, 6(1), 63 - 73

[45] Paprika, Z.Z., 2000. Knowledge management support in decision making. In IFIP WG 8.3 International Conference on Decision Support Systems, Stockholm, Sweden.

[46] Rolland Nicolas, 2004. Knowledge management impacts on decision making process. Journal of Knowledge Management, $\quad 8(1), \quad 20-31$ http://dx.doi.org/10.1108/13673270410523880

[47] Reed, K. K., Lubatkin, M., \& Srinivasan, N. 2006. Proposing and testing an intellectual capital-based view of the firm. Journal of Management Studies, 43(4): 867893.

[48] Riaz, M. N., \& Khalili, M. T. 2014. Transformational, transactional leadership and rational decision making in services providing organizations: Moderating role of knowledge management processes. Pakistan journal of commerce and social sciences, 8(2), 355-364.

[49] Sarantis, D., Charalabidis, Y. and Askounis, D. 2010, January. A goal oriented and knowledge based e- 
government project management platform. In IEEE. 43rd Hawaii International Conference on System Sciences (HICSS), 1-13.

[50] Sharabati, A. A. A., Naji Jawad, S., \& Bontis, N. .2010. Intellectual capital and business performance in the pharmaceutical sector of Jordan. Management decision, 48(1), 105-131.

[51] Subramaniam, M., \& Youndt, M. A. 2005. The influence of intellectual capital on the types of innovative capabilities. Academy of Management Journal, 48(3): 450-463.

[52] Ubogu, F.U., 2011. Knowledge Management for Decision Making: Tools, Institutions and Paradigms. In Proceedings of Second Meeting of Committee on Development Information (COMI)
[53] Wadhwa, S., \& Saxena, A. 2007. Decision knowledge sharing: flexible supply chains in KM context. Production Planning \& Control, 18(5), 436-452.

[54] Wiig, K. M. 1997. Integrating intellectual capital and knowledge management. Long range planning, 30(3), 399-405.

[55] Seleim, A.A. and Khalil, O.E., 2011. Understanding the knowledge management-intellectual capital relationship: a two-way analysis. Journal of Intellectual Capital, 12(4), pp.586-614.

[56] Ozlen, K., Handzic, M., \& Durmic, N. 2014. Empirical Study of KMS Impact on Decision Support. Eurasian Journal of Business and Economics, 7(13), 133-144.

[57] Goldberg, M., Pasher, E. and Levin-Sagi, M., 2006. Citizen participation in decision-making processes: knowledge sharing in knowledge cities. Journal of Knowledge Management, 10(5), pp.92-98. 